06

\title{
Анодный оксид алюминия, сформированный в водных растворах хелатных комплексных соединений цинка и кобальта
}

\author{
(C) A.A. Позняк, ${ }^{1}$ G.H. Knörnschild, ${ }^{2}$ A.H. Плиговка, ${ }^{1}$ Т.Д. Ларин ${ }^{1}$ \\ ${ }^{1}$ Белорусский государственный университет информатики и радиоэлектроники, \\ 220013 Минск, Беларусь \\ ${ }^{2}$ Universidade Federal do Rio Grande do Sul (UFRGS), \\ 91501970 Porto Alegre, Brasil \\ e-mail: poznyak@bsuir.by
}

Поступило в Редакцию 15 апреля 2021 г.

В окончательной редакции 15 апреля 2021 г.

Принято к публикации 15 апреля 2021 г.

\begin{abstract}
Представлены результаты гальваностатического анодирования специально подготовленного алюминия высокой чистоты в водных растворах комплексных соединений $\mathrm{K}_{3}\left[\mathrm{Co}\left(\mathrm{C}_{2} \mathrm{O}_{4}\right)_{3}\right]$ и $\mathrm{K}_{2}[\mathrm{Zn}(e d t a)]$ различной концентрации в диапазонах плотностей тока $1.5-1.10 \cdot 10^{2}$ и $1.5-30 \mathrm{~mA} \cdot \mathrm{cm}^{-2}$ соответственно. Установлены кинетические особенности анодирования, указывающие на протекание колебательного электрохимического процесса. Выявлены морфологические особенности, заключающиеся в нехарактерных для анодного оксида алюминия образованиях чешуйчатой и рыхлой природы для $\mathrm{K}_{2}[\mathrm{Zn}(e d t a)]$ и монолитных для $\mathrm{K}_{3}\left[\mathrm{Co}\left(\mathrm{C}_{2} \mathrm{O}_{4}\right)_{3}\right]$. Показаны элементный состав, ИК-спектроскопические и фотолюминесцентные характеристики сформированных оксидов.
\end{abstract}

Ключевые слова: анодный оксид алюминия, хелатные комплексные соединения, анодирование.

DOI: $10.21883 / J T F .2021 .10 .51360 .110-21$

\section{Введение}

Актуальным направлением нанотехнологий, бурно развивающимся в настоящее время, является создание наноразмерных структур и композитных материалов с использованием пористого анодного оксида алюминия (АОА) в качестве высокоупорядоченной наноструктурированной матрицы [1-3]. Ячеисто-пористая структура AOA предоставляет широкие возможности для управляемого варьирования его морфологических параметров, позволяя создавать широкий спектр функциональных материалов [4-10].

Важную роль в процессе формирования структуры анодных оксидов вентильных металлов: титана, гафния, ниобия, тантала, вольфрама, ванадия и циркония [11-14] играет состав электролита. Нужно сказать, что формирование пористых и трубчатых оксидов этих металлов стало возможным благодаря добавлению в электролиты анодирования небольших количеств фторид-ионов, являющихся лигандами, образующими прочные комплексные соединения со многими ионами металлов [15]. Состав электролита анодирования алюминия [16-18], и режимы проведения эксперимента [18-20] также существенно влияют на свойства и состав его анодного оксида. С точки зрения дополнительных возможностей для управления составом АOА большой интерес вызывают процессы получения АОА в электролитах, в составе которых присутствуют комплексные соединения и/или лиганды, способные образовывать устойчивые комплексные соединения [21].
Идея введения комплексообразующих добавок в электролиты для катодного осаждения покрытий не нова и является давно сложившейся практикой $[22,23]$. Процессы, связанные с переменнотоковым или катодным окрашиванием ранее сформированных слоев АОА, также зачастую подразумевают присутствие комплексообразующих органических реагентов [24]. Процесс модификации АОА, заключающийся в катодном осаждении антимонида индия в поры АОА, также подразумевает значительную концентрацию цитрат-анионов [3].

Следует сказать, что некоторые кислоты, используемые при приготовлении электролитов анодирования [25-28], обладают выраженной склонностью к образованию растворимых комплексных соединений с ионом алюминия [15]. Как было показано ранее [18], возможно специальное введение добавок веществ, содержащих лиганды, образующие устойчивые растворимые комплексные соединения с алюминием [15], что приводит к существенному изменению как характера процесса анодного оксидирования, так и морфологии его анодного оксида. Схожие исследования были проведены с использованием органического реагента арсеназо I (динатриевая соль 3-[(2-арсонофенил)азо]-4,5-дигидрокси-2,7нафталиндисульфокислоты), образующего исключительно устойчивые хелатные комплексы с ионом $\mathrm{Al}^{3+}$ и некоторыми другими [15]. Первое краткое сообщение на эту тему появилось еще в 2003 г. [29], после чего исследования были продолжены и представлены в ряде коротких сообщений [30-35]. В перечисленных работах было показано, что при увеличении концентрации арсеназо I происходит скачкообразное возрастание ско- 
рости растворения и падение значений максимального и стационарного напряжений кинетики анодирования; существует тенденция к увеличению пороговой концентрации добавки с ростом плотности анодного тока, а также исчезает феномен „горящей точки“, описанный, например, в [36-38], а в [31,32,39] авторы сообщили о том, что ими впервые было достигнуто аномально высокое содержание компонентов электролита, встроенных в структуру АОА непосредственно в процессе его формирования.

Возможно также введение добавок, образующих и устойчивые нерастворимые в электролите комплексные соединения, например, о-оксихинолин и/или его производные [15]. Анодирование в электролитах с подобными добавками приводит к улучшению электрофизических характеристик формируемого АОА [40] и изменению его спектрально-люминесцентных свойств [39].

Помимо введения в электролит анодирования добавок веществ, содержащих лиганды, способных образовывать растворимые или нерастворимые комплексные соединения с ионами анодируемого вентильного металла, возможен такой подход, когда добавка представляет собой заранее синтезированное устойчивое комплексное соединение, содержащее ион комплексообразователя другой природы, нежели ион анодируемого металла. Известно лишь небольшое количество исследований, посвященных этой теме [39,41,42].

В работах об анодировании в растворах комплексных соединений цинка и кобальта $[39,41]$ был упомянут феномен периодической осцилляции напряжения и обнаружена необычная морфология поверхности АОА. В работе, посвященной анодированию в присутствии хелатных комплексных соединений меди, было показано, что чем больше скорость роста оксида (большие напряжение и температура), тем больше меди включается в стенки оксида алюминия, что приводит к ухудшению регулярности расположения нанопор. Исследование фотолюминесценции (ФЛ) подтвердило включение хелатных комплексов меди [42].

Воспроизводимое и целенаправленной управление не только морфологией, но и составом АОА является актуальной задачей технической физики и материаловедения, решение которой позволило бы в процессе формирования создавать АОА с заданными электрофизическими характеристиками и морфологией, легировать стенки оксидных ячеек, придавая им проводниковые, полупроводниковые или особые оптические свойства, что, в свою очередь, расширяет область применения АОА. Одним из путей такого рода изменений электрофизических и/или оптических характеристик AOА и является анодирование в комплексообразующих растворах или растворах, содержащих комплексные соединения различных металлов. Несмотря на опыт практической апробации [40], данная тема не является изученной в достаточной мере. Существует небольшое количество публикаций, преимущественно тезисов конференций различного уровня, и еще меньшее количество статей. Описанные выше работы не формируют полное, конкретное представление о процессе получения АОА в электролитах с добавками или на основе комплексных соединений и нуждаются в дополнении и уточнении результатов. Настоящая работа призвана как дополнить результаты прошлых работ, так и более глубоко исследовать процесс анодирования в водных растворах хелатных комплексных соединений цинка и кобальта, охарактеризовать формируемый АОА и предоставить дополнительные сведения, для формирования общей картины процесса анодирования в указанных условиях.

\section{1. Методика проведения эксперимента}

\section{1. Подготовка алюминия для анодирования}

В настоящей работе был использован Al (99.999\%) и химические реактивы производства Aldrich Chemical Company. Толщина алюминия составляла $1 \mathrm{~mm}$. Для последующего анодирования алюминиевые листы разрезали на образцы необходимого размера с таким расчетом, чтобы анодируемая площадь составляла порядка $1 \mathrm{~cm}^{2}$. Для снятия внутренних напряжений и уменьшения количества дислокаций $[43,44]$ после нарезки образцов осуществляли их термическую обработку. Вначале образцы отжигали при температуре $753 \mathrm{~K}$ в течение $1 \mathrm{~h}$, затем охлаждали в воде комнатной температуры.

После термической обработки осуществляли механическую обработку образцов, которая заключалась в последовательном шлифовании и полировке металлической поверхности с обеих сторон. Образцы сначала шлифовали с применением специальной шлифовальной бумаги MicroCut для влажного шлифования с абразивом на основе $\mathrm{SiC}$ и зернистостью абразива 1200 в соответствии со стандартом ANSI, после чего осуществляли последовательную полировку на полировальных кругах с применением алмазных паст с размером зерна $3 \mu \mathrm{m}$ и доводку абразивной OPS-суспензией на основе оксида алюминия. Качество поверхности после обработки соответствовало 14-му классу чистоты.

В связи с относительно высокой стоимостью материалов в целях экономии многие из образцов использовали по 2-3 раза, при этом сначала снова проводили их термическую обработку, затем шлифовку и полировку по изложенной выше методике. Логично, что толщина таких образцов уменьшалась в зависимости от количества циклов до $0.7-0.3 \mathrm{~mm}$. Предполагается, что состав и свойства образцов при этом не изменялись.

Менисковую область перед анодированием защищали барьерным оксидом, формируемым в 1\% лимонной кислоте (структурная формула показана на рис. 1,a) в комбинированном режиме. Вначале в потенциодинамическом режиме разворачивали напряжение со скоростью $2.0 \mathrm{~V} \cdot \mathrm{s}^{-1}$, затем по достижении $290 \mathrm{~V}$ переходили в потенциостатический режим, прекращая анодирование 


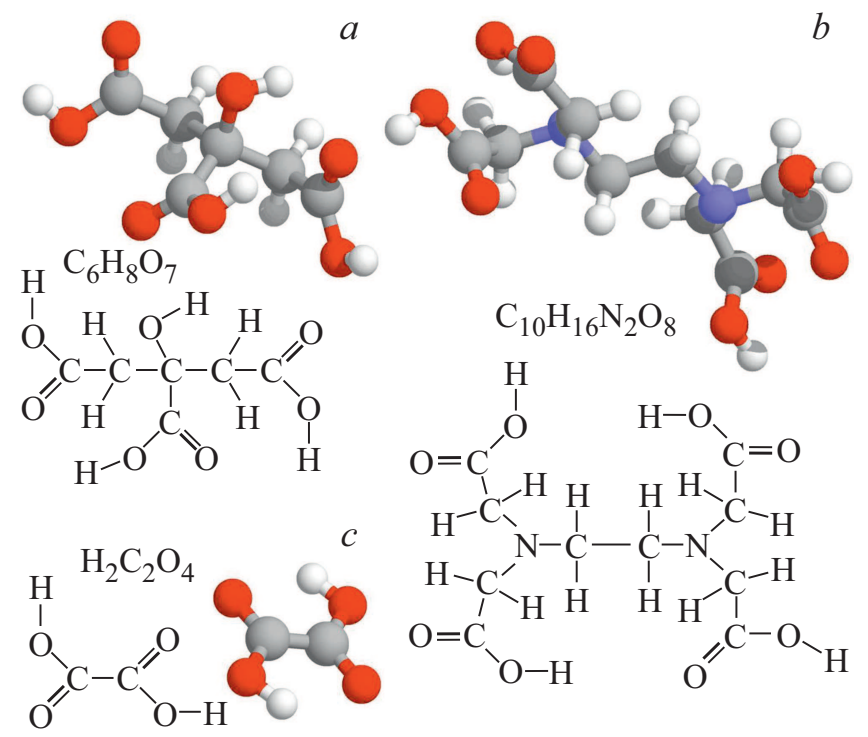

Рис. 1. Структурные формулы и трехмерные модели молекул органических кислот: $a-$ лимонной, $b-$ этилендиаминтетрауксусной и $c$ - щавелевой.

по достижении током значения порядка 1\% от начального. Анодирование осуществляли в гальваностатическом (ГСт) режиме $\left(j_{a}=\right.$ const $)$ в стеклянной электрохимической ячейке с плоским платиновым катодом, сравнимым по площади с анодом; анод и катод были расположены вертикально и параллельно друг другу, при этом одна сторона анодируемого образца была ориентирована к катоду, другая — в противоположную сторону.

\section{2. Электролиты анодирования}

Электролиты анодирования представляли собой водные растворы комплексных соединений Сo (III) и $\mathrm{Zn}(\mathrm{II})$, синтезированных по описанным ниже методикам. Методики приготовления растворов комплексных соединений кобальта и цинка принципиально одинаковы. Вначале происходило осаждение гидроксида соответствующего металла из водного раствора его сульфата путем приливания раствора гидроксида калия, добавляемого к раствору сульфата в эквивалентном количестве (уравнение (1)). Сульфатам было отдано предпочтение, например, по сравнению с хлоридами, прежде всего, потому что небольшие примеси хлорид-ионов, которые могли бы присутствовать в синтезируемых соединениях даже после тщательной их очистки, могли сделать невозможным дальнейшее осуществление процесса анодирования алюминия и/или его сплавов из-за питтинга [45]. В качестве осаждающего агента предпочтение было отдано гидроксиду калия по сравнению, например, с гидроксидом натрия, поскольку, как известно, ион натрия обладает весьма высокой подвижностью, что делает его присутствие весьма нежелательным в технологических процессах производства элементной базы устройств микроэлектроники.
Осадок отсасывали на плотном бумажном фильтре с помощью водоструйного насоса и многократно промывали дистиллированной водой. Затем, для получения этилендиаминтетраацетатного комплекса (уравнение (2)) осадок вместе с фильтровальной бумагой переносили в заранее приготовленный раствор дикалиевой соли этилендиаминтетрауксусной кислоты (структурная формула изображена на рис. $1, b)$. Растворение гидроксида металла происходило при интенсивном перемешивании. Все реакции были осуществлены как можно быстрее и при комнатной температуре, без нагревания, для предотвращения разложения нестойких гидроксидов вследствие отщепления воды (уравнение (3)), что могло бы, в свою очередь, осложнить протекание реакции комплексообразования.

$$
\begin{aligned}
\mathrm{ZnSO}_{4}+2 \mathrm{KOH} & \rightarrow \mathrm{Zn}(\mathrm{OH})_{2 \downarrow}+\mathrm{K}_{2} \mathrm{SO}_{4}, \\
\mathrm{Zn}(\mathrm{OH})_{2}+\mathrm{K}_{2} \mathrm{H}_{2} \text { edta } & \rightarrow \mathrm{K}_{2}[\mathrm{Zn}(\text { edta })]+\mathrm{H}_{2} \mathrm{O} \\
\mathrm{Zn}(\mathrm{OH})_{2} & \rightarrow \mathrm{ZnO}+\mathrm{H}_{2} \mathrm{O}
\end{aligned}
$$

Затем растворы фильтровали и после соответствующего разбавления использовали для анодирования. Аналогичным образом было синтезировано комплексное соединение кобальта состава $\mathrm{K}_{3}\left[\mathrm{Co}\left(\mathrm{C}_{2} \mathrm{O}_{4}\right)_{3}\right]$ (координационное число кобальта в степени окисления +2 и +3 равно, как правило, шести), но вместо $\mathrm{K}_{2} \mathrm{H}_{2}$ edta использовали щавелевую кислоту (рис. $1, c$ ).

\section{3. Приборы и оборудование}

Состав полученных экспериментальных образцов изучали методом рентгеновской фотоэлектронной спектроскопии (РФС) (Physical Electronics PHI 5600XРspectrometer), ИК спектроскопии со спектральным разрешением $1 \mathrm{~cm}^{-1}$ (Perkin-Elmer-180) и оже-электронной спектроскопии (Physical Electronics PHI 670). Электронно-микроскопические исследования осуществляли с помощью сканирующих электронных микроскопов JEOL JSM 6400 и Hitachi S4800 с электронно-зондовой приставкой Genesis 4000. Оптические изображения получали на микроскопе Микро 200-01. Спектры фотолюминесценции были получены с использованием спектрофлуориметра SFL-1211 А при спектральной ширине щели $1 \mathrm{~nm}$. Рентгенодифракционные спектры были получены на модернизированной установке ДРОН-3 с использованием $\mathrm{Cu} K_{\alpha}$-излучения и графитового фильтра с шагом сканирования $0.04^{\circ}$ и экспозицией в каждой точке $3 \mathrm{~s}$ в диапазоне $2 \theta 15-100^{\circ}$.

\section{2. Результаты и обсуждение}

В случае анодирования алюминия в электролите, представляющем собой водный раствор комплексного соединения состава $\mathrm{K}_{2}[\mathrm{Co}($ edta $)](0.75 \mathrm{M}$, $\left.1.5 \mathrm{~mA} \cdot \mathrm{cm}^{-2}\right)$, имело место ярко выраженное явление „подгорания“, характеризовавшееся осцилляциями 

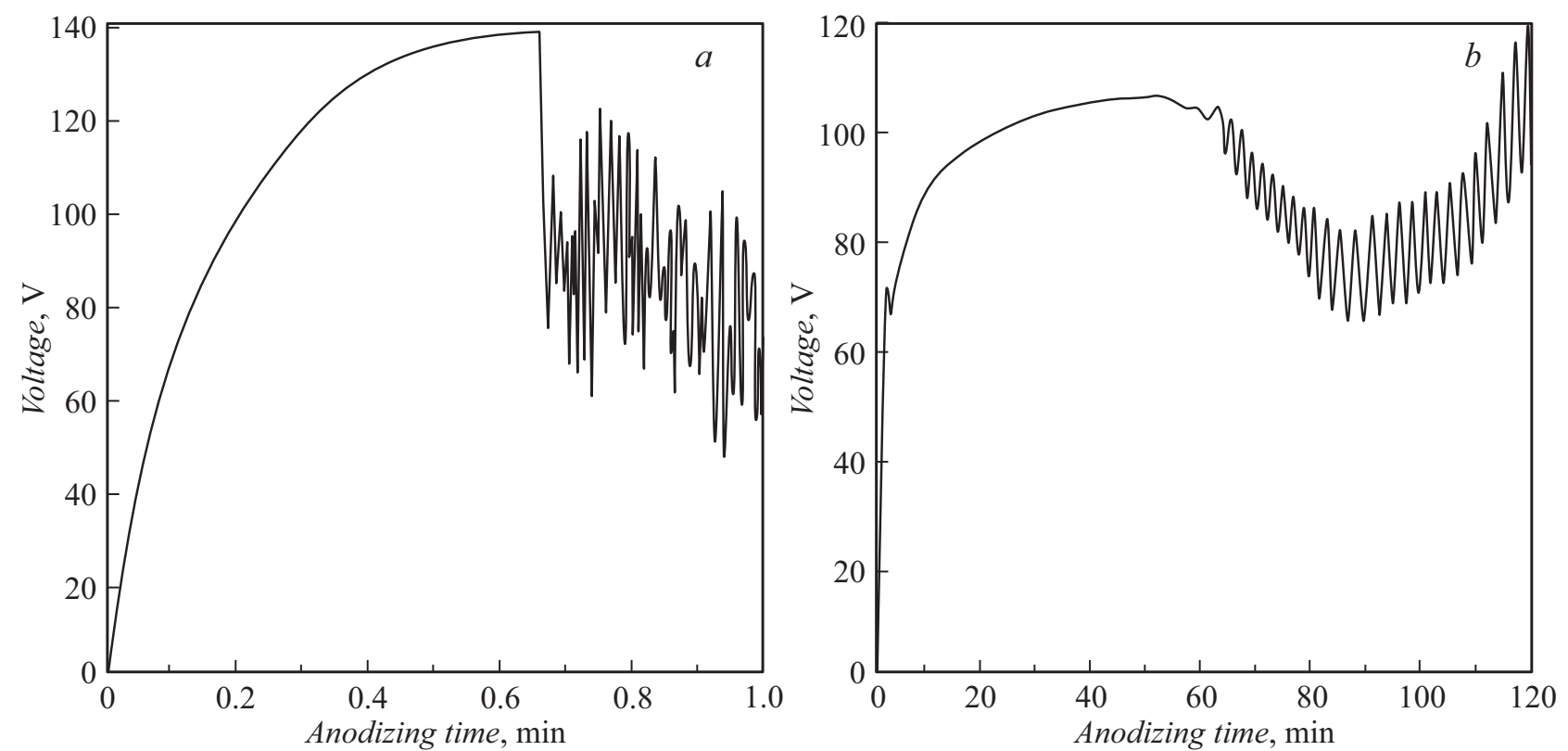

Рис. 2. Кинетики анодирования $\mathrm{Al}$ в $0.75 \mathrm{M}$ водном растворе $e d t a$-комплекса Со при плотности тока $j_{a} 1.5 \mathrm{~mA} \cdot \mathrm{cm}^{-2}(a)$ и в $0.5 \mathrm{M}$ водном растворе $\mathrm{K}_{2}[\mathrm{Zn}(e d t a)]$ при плотности тока $j_{a} 5 \mathrm{~mA} \cdot \mathrm{cm}^{-2}(b)$.

анодного напряжения на кинетике, несмотря на интенсивное перемешивание и невысокие значения плотностей анодного тока; подобное явление описано в [46]. Типичная кинетика протекания анодного процесса в данном электролите приведена на рис. 2, a. Совершенно иная картина наблюдалась при анодировании образцов высокочистого алюминия в растворе $\mathrm{K}_{2}[\mathrm{Zn}(e d t a)]$ [41]. Концентрация комплексной соли во всех случаях составляла $0.5 \mathrm{M}$, плотность анодного тока $j_{a}$ варьировали в пределах $1.5-30 \mathrm{~mA} \cdot \mathrm{cm}^{-2}$. Кинетика анодирования (временная зависимость анодного напряжения $U_{a}$ ) одного из образцов показана на рис. $2, b$.

Анодный процесс, осуществляемый в растворе $\mathrm{K}_{2}[\mathrm{Zn}(e d t a)]$, имеет ряд существенных кинетических особенностей. Вначале, как и в кислотных электролитах, наблюдается почти линейный рост анодного напряжения со временем до максимального значения, затем напряжение несколько уменьшается, после чего, вместо перехода в стационарный режим происходит довольно значительный, постепенно замедляющийся рост анодного напряжения. По прошествии времени порядка нескольких десятков минут, когда рост $U_{a}$ уже практически не происходит, начинаются периодические осцилляции напряжения. Значение $U_{a}$ достигает в максимуме порядка $\sim 100 \mathrm{~V}$, а амплитуда колебаний составляет до $20 \mathrm{~V}$. При продолжительности анодирования до $120 \mathrm{~min}$ прекращения осцилляций не происходило. На этом явлении следует остановиться отдельно. На сегодняшний день известно большое число колебательных химических реакций [47], а первые явления, относящиеся к колебательному поведению электрохимических систем, отмечены еще в начале XIX века [48]. C тех пор накоплено значительное количество экспериментальных результатов исследований явлений самоорганизации, происходящих при протекании электродных процессов. До недавнего времени были известны четыре группы колебательных электрохимических реакций [48]. Это осцилляции, в ряде случаев происходящие при:

- анодном растворении металлов;

- анодном окислении неметаллических веществ (главным образом органических соединений и водорода);

- катодном осаждении металлов;

- электровосстановлении анионов.

Как можно заметить, периодические реакции, происходящие во время анодного пассивирования, до настоящего времени не наблюдались. Поэтому всестороннее исследование полученных пленок представляет особый интерес.

На рис. 3, $a-c$ показаны электронно-микроскопические изображения поверхностей образцов, проанодированных в $0.5 \mathrm{M}$ растворе $\mathrm{K}_{2}[\mathrm{Zn}($ edta $)]$ при различных значениях $j_{a}$. Заметно, что уже при малой плотности тока $\left(1.5 \mathrm{~mA} \cdot \mathrm{cm}^{-2}\right)$ и получасовой продолжительности анодирования на поверхности образуются выступы, которые при повышении плотности тока $\left(4.0 \mathrm{~mA} \cdot \mathrm{cm}^{-2}\right)$ и продолжительности процесса на протяжении двух часов сливаются в сплошные растрескивающиеся поля. При дальнейшем повышении $j_{a}\left(10.0 \mathrm{~mA} \cdot \mathrm{cm}^{-2}\right)$ и анодировании в течение $20 \mathrm{~min}$ происходит образование „чешуйчатых“ (или „рыхлых“) выступов, размеры и поверхностная плотность которых растут с дальнейшим увеличением продолжительности анодирования и повышением плотности тока до $25 \mathrm{~mA} \cdot \mathrm{cm}^{-2}$. Электронномикроскопическое изображение трещины, сделанное при большом увеличении, приведено на рис. $3, d$. Видно, что 

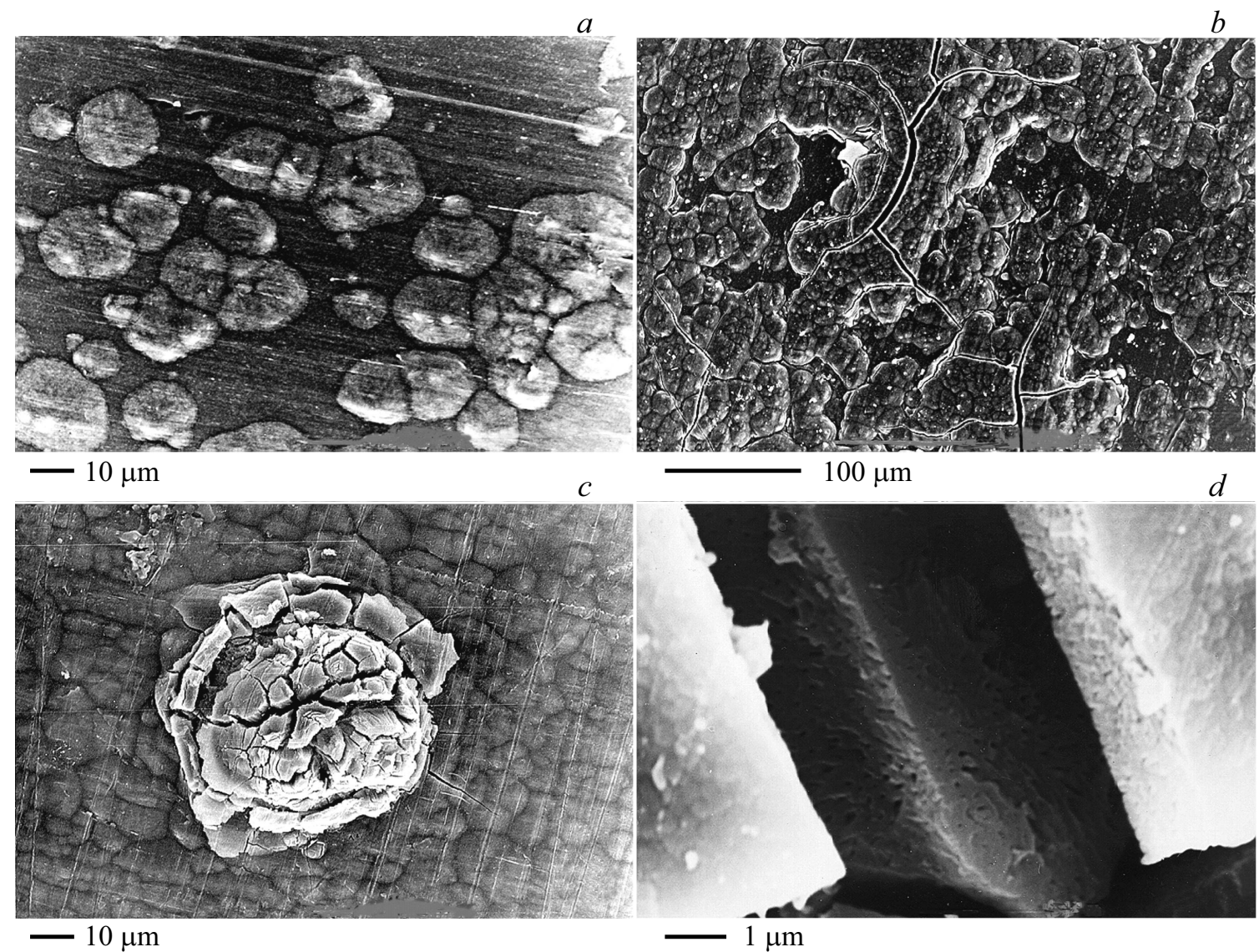

$100 \mu \mathrm{m}$

$d$

$10 \mu \mathrm{m}$

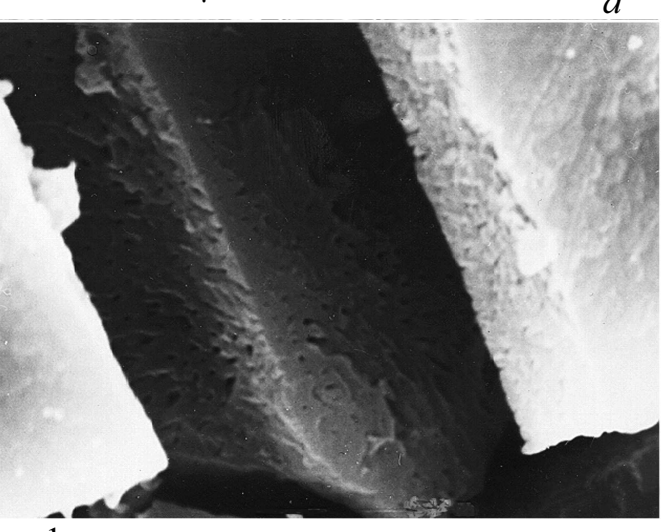

$1 \mu \mathrm{m}$

Рис. 3. Микрофотографии поверхности АОА, сформированного в $0.5 \mathrm{M}$ растворе $\mathrm{K}_{2}[\operatorname{Zn}(e d t a)]$ при $j_{a} \quad 1.5$ (a), 4.0 (b) и $10.0 \mathrm{~mA} \cdot \mathrm{cm}^{-2}(c)$ в течение $30 \mathrm{~min}, 2 \mathrm{~h}$ и $20 \mathrm{~min}$ соответственно, и трещины на поверхности АОА, сформированного в течение $2.5 \mathrm{~h}$ при плотности тока $14.0 \mathrm{~mA} \cdot \mathrm{cm}^{-2}(d)$.

AOA на изломе трещины имеет ячеисто-пористую структуру. Визуально представленные на рис. 3 образования напоминают объекты, изображенные на СЭМ изображениях в работах прошлых лет, посвященных анодированию алюминия в различных кислотах [49-51], в недавно опубликованной работе [20], а также микроконусы, растущие при анодировании титана [52,53]. Это наблюдение может свидетельствовать об общем характере причин, приводящих к возникновению таких образований. Вероятно, происходит локальное перераспределение плотности тока и концентрации различающихся по природе ионов, в той или иной мере упорядоченное, которое может приводить как к росту более или менее регулярно расположенных микровыступов [20,52,53], так и к образованию случайно расположенных пробоев [49-51].

Появление „гладких“ при небольших значениях $j_{a}$ и „чешуйчатых“ выступов при дальнейшем повышении плотности анодного тока можно объяснить тем, что примесные анионы небольшого размера, присутствующие в растворе в следовых количествах, в результате перераспределения плотности тока концентрируются вблизи определенных участков поверхности и обусловливают локальную неравномерную проводимость электролита. Кроме того, примеси могут встраиваться в АОА как равномерно по всей площади, так и неравномерно [16]. В последнем случае тот участок оксида, где находится больше анионов, имеет более высокую проводимость, что приводит к увеличению скорости его роста. Таким образом, вероятно, и в нашем случае возникают неравномерности рельефа при анодировании в изученных растворах комплексных соединений.

В настоящей работе был осуществлен также анализ пленок AOA, полученных методом электрохимического ГСт анодирования алюминия в раствоpe $\mathrm{K}_{2}[\mathrm{Zn}(e d t a)]$ методами электронного зонда, ожеспектроскопии и РФС. Для случая диэлектрических материалов, каковым является $\mathrm{Al}_{2} \mathrm{O}_{3}$, РФС анализ сопряжен с определенными трудностями в интерпретации полученных спектров [54]. При осуществлении анализов этим методом происходит накопление заряда на образцах, поэтому было необходимо производить корректировку положений пиков по оже-пику кислорода, что позволило определить энергии связи электронов и валентное состояние элементов. Оже-электронные и РФС анализы показали наличие в составе АОА примеси углерода, азота и серы. На рис. 4 показаны результаты анализа „рыхлого“ выступа образца, полученного анодированием в течение $55 \mathrm{~min}$ при плотности анодного тока 

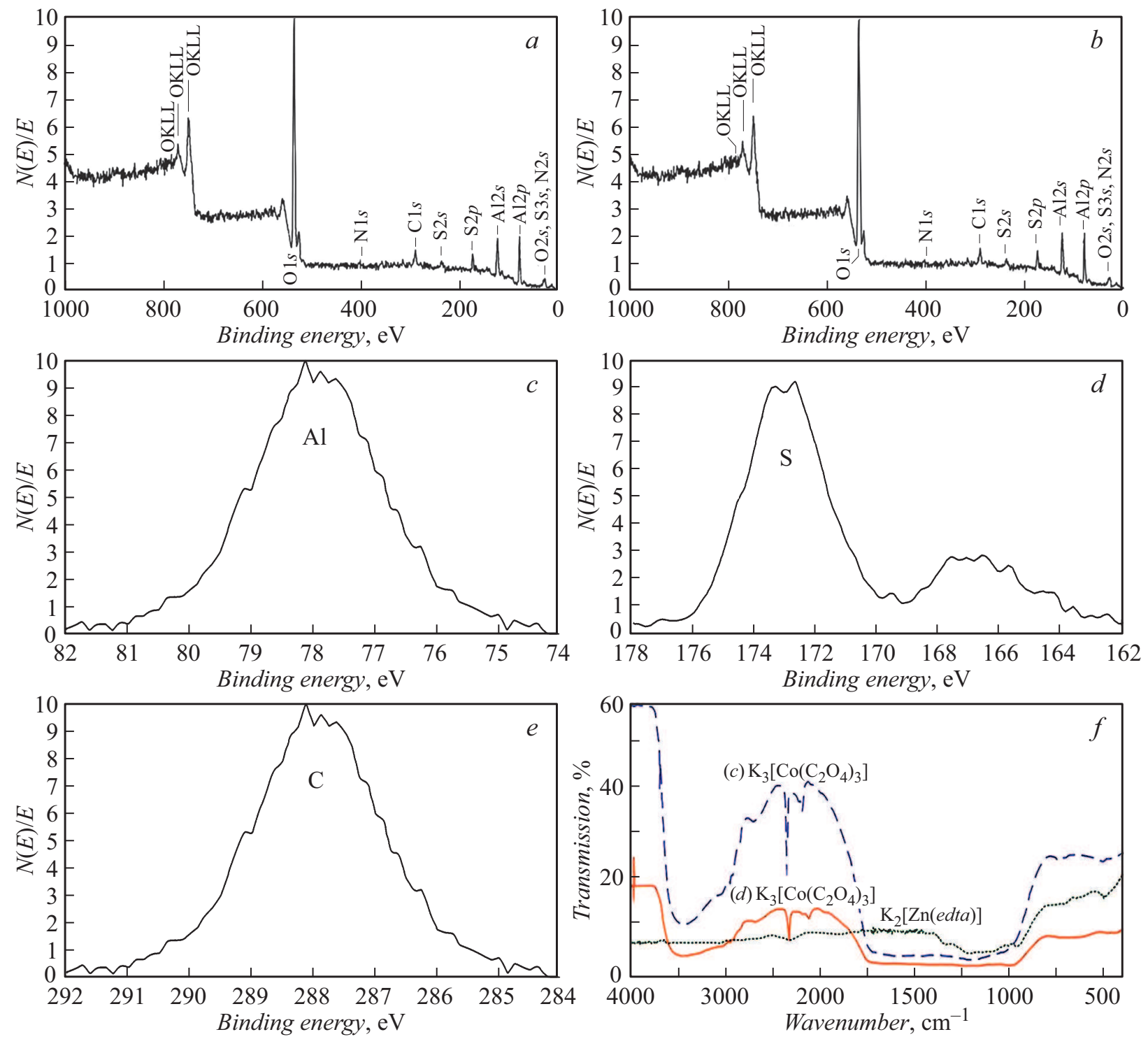

Рис. 4. РФС обзор „рыхлого“ выступа образца, полученного анодированием в течение 55 тіп при плотности анодного тока $25 \mathrm{~mA} \cdot \mathrm{cm}^{-2}$ после обычной $(a)$ и продолжительной промывки $(b)$. РФС идентификация валентного состояния элементов (алюминия $(c)$, серы $(d)$ и углерода $(e))$ в составе „рыхлого“ выступа; ИК спектры пропускания образца $(f)$, сформированного в $0.5 \mathrm{M}$ растворе $\mathrm{K}_{2}[\mathrm{Zn}(e d t a)]$ в течение $55 \mathrm{~min}$ при плотности анодного тока $25 \mathrm{~mA} \cdot \mathrm{cm}^{-2}$, и образцов, изображенных на рис. $6, c, d$.

$25 \mathrm{~mA} \cdot \mathrm{cm}^{-2}$ после обычной (рис. $\left.4, a\right)$ и продолжительной промывки (рис. 4, $b$ ), а на рис. $4, c-e-$ результаты анализа состояния некоторых элементов, входящих в состав этого же объекта.

Образцы промывали в дистиллированной воде комнатной температуры при непрерывном перемешивании в объеме $\sim 100 \mathrm{~mL}$, трижды меняя промывочную воду; общая продолжительность промывки составляла $\sim 15 \mathrm{~min}$. Повторный анализ был осуществлен после пятикратной промывки в тех же условиях, но общей продолжительностью около $5 \mathrm{~h}$. Как видно из результатов анализа, сера, предположительно находящаяся в виде сульфатаниона, входит в состав оксида, а не сорбирована рыхлой структурой выступающего образования на поверхности, так как не была смыта после столь длительной промывки. В результате анализа валентного состояния элементов оказалось, что оксид алюминия находится в виде $\alpha$ - или $\gamma$-модификации (более точная идентификация данным методом невозможна); углерод связан неполярной или слабополярной связью (типа $\mathrm{C}-\mathrm{C}$, $\mathrm{C}-\mathrm{H}$ или $\mathrm{C}-\mathrm{S}$ ); а сера присутствует в окисленном состоянии (т.е. действительно находится в виде сульфатаниона). Присутствие серы объясняется, по всей видимости, загрязнением синтезированного комплексного соединения сульфатом калия; а сульфат-анион, несмотря на следовое содержание в электролите, в силу малого ионного радиуса и более высокой подвижности эффективней встраивается в образующийся оксид. УГлерод мог попасть в пленку АОА только вместе с кислотным остатком edta. В пользу последнего утверждения 

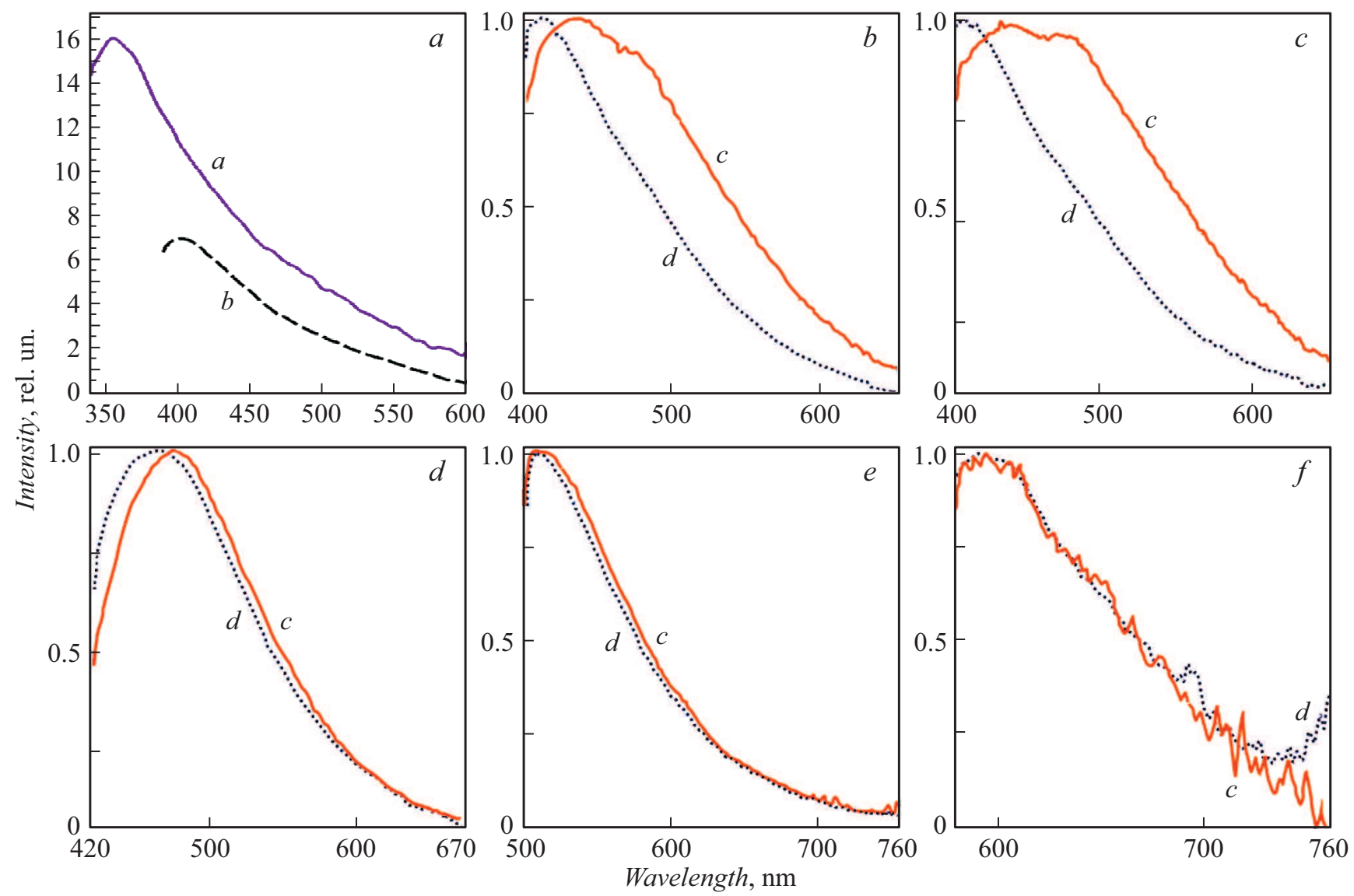

Рис. 5. Спектры ФЛ образца АОА, полученного $(a)$ в $0.5 \mathrm{M}$ растворе $\mathrm{K}_{2}[\mathrm{Zn}(e d t a)]$ в течение 55 min при плотности анодного тока $25 \mathrm{~mA} \cdot \mathrm{cm}^{-2}$ (сплошная линия $a$ и штриховая линия $b$ соответствуют длинам волн возбуждения 260 и $340 \mathrm{~nm}$ ), и в $1.9 \mathrm{M}$ растворе $\mathrm{K}_{3}\left[\mathrm{Co}\left(\mathrm{C}_{2} \mathrm{O}_{4}\right)_{3}\right]$ в течение $29 \mathrm{~min}$ при $j_{a}=1.10 \cdot 10^{2} \mathrm{~mA} \cdot \mathrm{cm}^{-2}$ при длинах волн возбуждения $270(b), 308(c), 370(d), 415(e)$ и $520 \mathrm{~nm}(f)$ (сплошные линии с соответствуют ФЛ поверхности, обращенной к катоду и изображенной на рис. 6, $c$, пунктирные линии $d$ соответствуют ФЛ поверхности, обращенной от катода и изображенной на рис. $6, d)$.

свидетельствует и наличие в оксиде примеси азота, также входящего в состав этилендиаминтетрауксусной кислоты. Анализ не показал сигнала от сильнополярных связей $\mathrm{C}=\mathrm{O}, \mathrm{C}-\mathrm{O}$, поскольку, во-первых, доля таких атомов в edta ${ }^{4-}$-анионе мала по сравнению с числом атомов, связанных слабополярной либо неполярной связью, а, во-вторых, общее количество углерода в пленке незначительно. Однако приведенные результаты анализа косвенно свидетельствуют о присутствии цинка в составе полученного АОА, который не мог не проникнуть в пленку в составе чрезвычайно прочного комплексного хелатного этилендиаминтетраацетатного двухзарядного аниона $[\operatorname{Zn}(e d t a)]^{2-}[15]$. И, действительно, с помощью электронно-зондовых исследований были обнаружены в составе оксида также примеси цинка. Количество каждого из примесных элементов не превышает $\sim 1$ at.\%. Примеси обусловлены проникновением компонентов электролита в структуру АОА.

На рис. 5, а представлены спектры ФЛ АОА, полученного анодированием в растворе $\mathrm{K}_{2}[\operatorname{Zn}($ edta $)]$ течение $55 \mathrm{~min}$ при плотности анодного тока $25 \mathrm{~mA} \cdot \mathrm{cm}^{-2}$ при длинах волн возбуждения 260 и $340 \mathrm{~nm}$. Из рисунка видно, что при указанных значениях $\lambda_{\text {в }}$ спектры ФЛ этого образца практически не отличаются от спектров образцов, полученных в традиционных кислотных электролитах. В то же время образец очень сильно поглощает не только в видимой области, но и в ИК диапазоне. На рис. 4, $f$ приведен спектр пропускания этим же образцом ИК излучения в широком диапазоне волновых чисел. Даже в наиболее длинноволновой области $\left(800-400 \mathrm{~cm}^{-1}\right)$ - области наибольшей прозрачности данного образца, относительное пропускание едва достигает 20\%. Из-за крайне высокого поглощения и невыраженности минимумов пропускания даже при высокой чувствительности ИК спектрометра анализ и расшифровка спектра затруднена.

Был осуществлен также ряд экспериментов по анодированию образцов высокочистого алюминия в ГСт режиме в растворе оксалатного хелатного комплекса кобальта состава $\mathrm{K}_{3}\left[\mathrm{Co}\left(\mathrm{C}_{2} \mathrm{O}_{4}\right)_{3}\right]$. Концентрация электролита в экспериментах составляла 1.1 и $1.9 \mathrm{M}$, плотность тока варьировали в пределах $1.5-1.10 \cdot 10^{2} \mathrm{~mA} \cdot \mathrm{cm}^{-2}$. Кинетика анодирования в целом похожа на описанную для случая этилендиаминтетраацетатного комплек- 

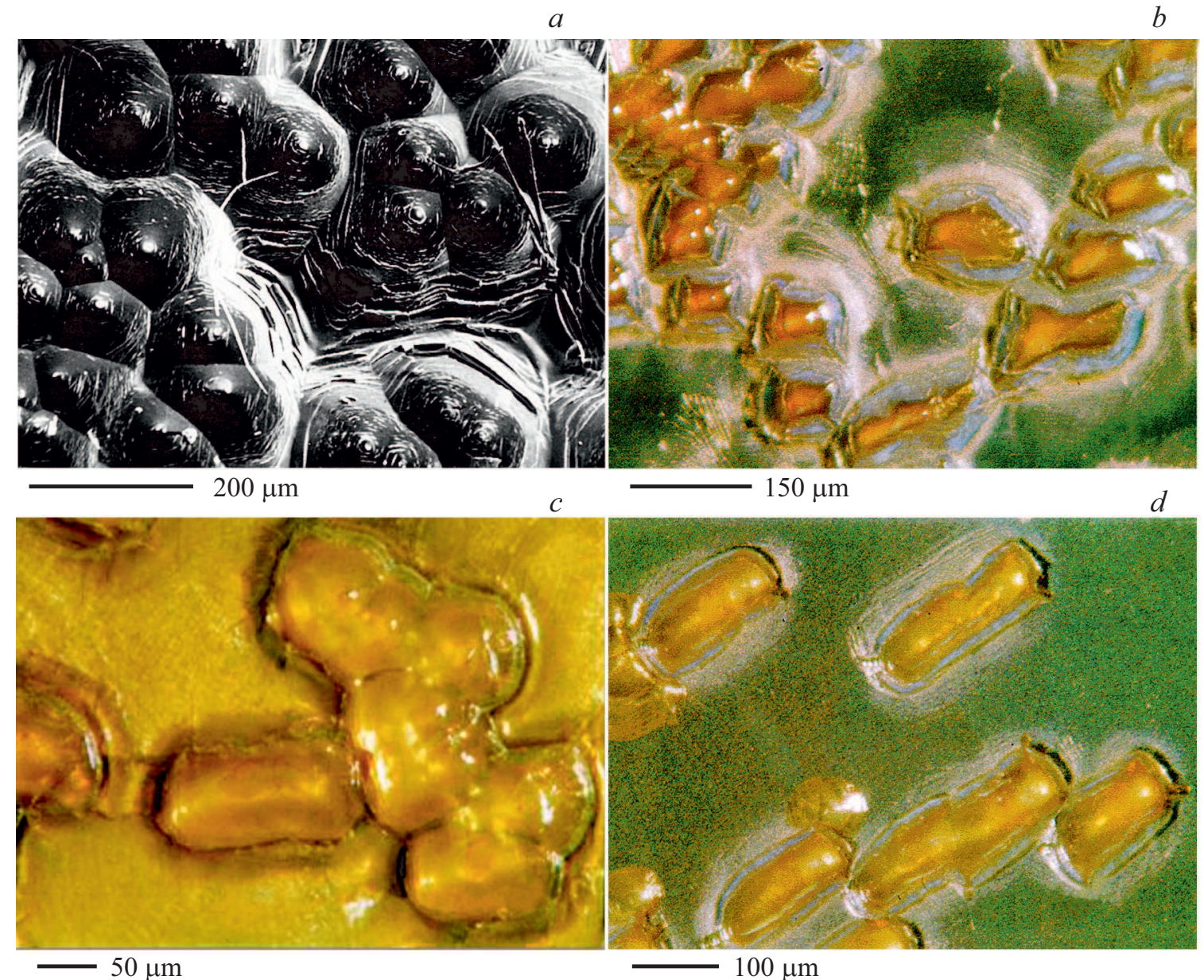

$d$

Рис. 6. Изображения поверхности анодного оксида алюминия, полученного анодированием в течение $74 \mathrm{~min}$ в $1.9 \mathrm{M}$ растворе $\mathrm{K}_{3}\left[\mathrm{Co}\left(\mathrm{C}_{2} \mathrm{O}_{4}\right)_{3}\right]$ при плотности тока $50.0 \mathrm{~mA} \cdot \mathrm{cm}^{-2}$, снятые с помощью электронного $(a)$ и оптического $(b)$ микроскопов; оптические фотоизображения АОА, полученного анодированием в $1.9 \mathrm{M}$ растворе $\mathrm{K}_{3}\left[\mathrm{Co}\left(\mathrm{C}_{2} \mathrm{O}_{4}\right)_{3}\right]$ в течение 29 min при $j_{a}=1.10 \cdot 10^{2} \mathrm{~mA} \cdot \mathrm{cm}^{-2}$, на стороне, обращенной к катоду $(c)$, и в противоположную сторону $(d)$.

са цинка, но, во-первых, значения анодного напряжения в максимуме едва достигали $100 \mathrm{~V}$, во-вторых, частота осцилляций была выше, а амплитуда составляла $\sim 1 \mathrm{~V}$.

Изображения поверхности АОА, сформированного анодированием $\mathrm{Al}$ в течение $74 \mathrm{~min}$ в $1.9 \mathrm{M}$ раствоpe $\mathrm{K}_{3}\left[\mathrm{Co}\left(\mathrm{C}_{2} \mathrm{O}_{4}\right)_{3}\right]$ при плотности тока $50.0 \mathrm{MA} \cdot \mathrm{cm}^{-2}$, полученные с помощью электронного и оптического микроскопов, представлены на рис. 6, a,b. Благодаря более высокой разрешающей способности и глубине резкости электронного микроскопа [55] можно более четко рассмотреть характер поверхности образца, в то время как оптическое изображение позволяет показать окраску образовавшейся АОА. Видно, что на относительно ровной поверхности АОА расположены выступающие образования конической формы или похожие на четырехугольную пирамиду, которые, сливаясь, образуют при определенных условиях сплошные поля. Характер и общая площадь этих образований зависит от электрического режима анодирования и ориентации анодируемого образца относительно катода. На рис. 6 представлены оптические фотоизображения АОА, полу- ченного анодированием в $1.9 \mathrm{M}$ растворе $\mathrm{K}_{3}\left[\mathrm{Co}\left(\mathrm{C}_{2} \mathrm{O}_{4}\right)_{3}\right]$ в течение $29 \mathrm{~min}$ при $j_{a}=1.10 \cdot 10^{2} \mathrm{~mA} \cdot \mathrm{cm}^{-2}$ (сторона, обращенная к катоду (рис. 6,c), и противоположная от катода сторона (рис. 6, $d)$ ). Количество образований выше и их размер больше у образцов, полученных при более высоких плотностях анодного тока, а также на стороне, ориентированной к катоду, для них характерно отсутствие растрескивания и „шелушения“ при любой плотности тока. То есть толщина оксида на стороне анода, обращенной к катоду, выше, чем на обратной стороне, что следует не только из рассмотрения рис. $6, c, d$, но и косвенно подтверждается результатами исследования фотолюминесцентных и ИК спектроскопических свойств, а также спектрами рентгеновской дифракции (рис. 7). Такое влияние свидетельствует о невысокой рассеивающей способности использованного электролита. Термин рассеивающая способность существует для оценки равномерности распределения тока на электродах, что означает способность электролита при данных условиях электролиза давать более или менее равномерные по толщине покрытия [56]. 


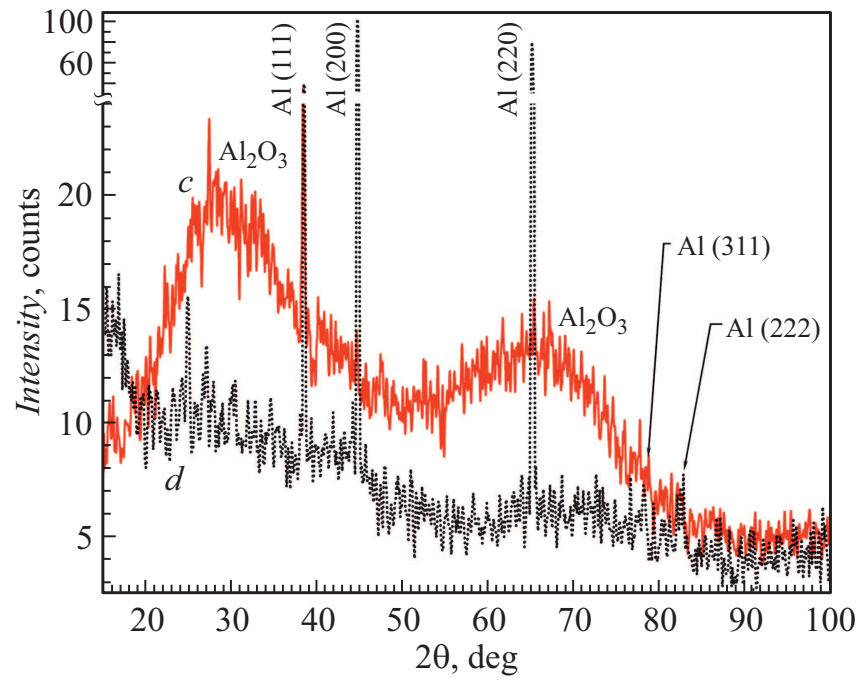

Рис. 7. Рентгенодифракционные спектры образца, полученного в $1.9 \mathrm{M}$ растворе $\mathrm{K}_{3}\left[\mathrm{Co}\left(\mathrm{C}_{2} \mathrm{O}_{4}\right)_{3}\right]$ в течение $29 \mathrm{~min}$ при $j_{a}=1.10 \cdot 10^{2} \mathrm{~mA} \cdot \mathrm{cm}^{-2}$ (сплошная линия $c$ соответствует поверхности, обращенной к катоду и изображенной на рис. $6, c$, пунктирная линия $d$ соответствует поверхности, обращенной от катода и изображенной на рис. $6, d$ ).

Установлено, что наличие упомянутых выступов обусловливает существенные различия ФЛ свойств по сравнению с другими пленками, полученными в аналогичных условиях. На рис. $5, b-f$ показаны спектры ФЛ разных сторон одного и того же образца, представленного на рис. $6, c, d$, и снятые при различных длинах волн возбуждения $\left(\lambda_{\mathrm{B}} 270,308,370,415\right.$ и $\left.520 \mathrm{~nm}\right)$. Кривая с на графиках соответствует спектру АОА на стороне образца, ориентированной по направлению к катоду, а кривая $d$ - на стороне, обращенной во время анодирования от катода. Все спектры люминесценции на рис. $5, b-f$ нормированы на единицу. Очевидны различия в характере приведенных спектров. Во-первых, спектр поверхности с большим количеством выступающих образований сильно сдвинут в более длинноволновую область, а, вовторых, с появлением на поверхности образца выступов возникает и ярко выраженный второй максимум, расположенный также в более длинноволновой области, чем основной, который исчезает при увеличении длины волны возбуждения. Обе особенности проявляются сильнее при уменьшении длины волны возбуждающего света. Этот факт свидетельствует о наличии в составе выступов центров люминесценции, возбуждаемых более короткими волнами. Определение природы этих центров и выявление различий структуры и состава слоев АOА с выступами и без них требует дальнейших исследований.

На рис. 4,f представлены ИК спектры образца, полученного анодированием алюминия в растворе $\mathrm{K}_{3}\left[\mathrm{Co}\left(\mathrm{C}_{2} \mathrm{O}_{4}\right)_{3}\right]$ и представленного на рис. $6, c, d$. Кривая $c$ на графиках соответствует спектру АОА стороны образца, ориентированной поверхностью по направлению к катоду, а кривая $d-$ стороны, обращенной во время анодирования от катода (обе поверхности представлены на рис. 6, изображения $c$ и $d$ соответственно). По сравнению с аналогичными спектрами, характерными для электролитов, не содержащих добавок комплексных соединений кобальта, появились новые полосы поглощения. Полосы, находящиеся в областях 3750-2800 и $2100-800 \mathrm{~cm}^{-1}$, чрезвычайно широки и интенсивны даже при малой чувствительности спектрометра. Появились также не столь интенсивные, но очень узкие полосы поглощения с острыми минимумами в области волновых чисел около 2350 и $2150 \mathrm{~cm}^{-1}$ (последняя полоса двойная). В попытке рассмотреть указанные полосы чувствительность прибора была снижена настолько, что обычно хорошо выраженная широкая интенсивная полоса поглощения в области $1000-400 \mathrm{~cm}^{-1}$, состоящая на самом деле из нескольких полос и принадлежащая валентным колебаниям $\mathrm{Al}-\mathrm{O}$, практически неразличима.

В работе [57] подробно рассмотрены вопросы ИК спектроскопического анализа АОА, полученных в водных растворах серной, ортофосфорной, щавелевой и малоновой кислот, и показано, что АОА, сформированный в указанных электролитах, обладает низкой (на пределе чувствительности спектрофотометра) степенью гидратации и малой концентрацией бёмита в нем. Интересно присутствие интенсивных полос поглощения в интервале $3700-3000$ и вблизи частоты $1060 \mathrm{~cm}^{-1}$, свидетельствующих о появлении в нашем случае новой фазы в виде включений три- и моногидратов Al, которые обычно возникают лишь в результате обработки в горячей $(340-373 \mathrm{~K})$ воде. В случае же АОА, полученного в растворе комплексной соли кобальта, мы имеем весьма интенсивное поглощение как в перечисленных областях, так и в коротковолновой ИК области вблизи $3800-3300 \mathrm{~cm}^{-1}$, соответствующее валентным колебаниям координированных и адсорбированных ОН-групп, а также поглощение в среднечастотной области вблизи $1620 \mathrm{~cm}^{-1}$, относящееся к деформационным колебаниям связи $\mathrm{Al}-\mathrm{OH}$ три- и моногидроксидов $\mathrm{Al}$ и на частоте $1080 \mathrm{~cm}^{-1}$, характеризующее валентные колебания в первичном бёмите.

Таким образом, фазовый состав и степень гидратации АОП алюминия, полученных в „традиционных“ кислотных электролитах и исследованном электролите, представляющем собой раствор $\mathrm{K}_{3}\left[\mathrm{Co}\left(\mathrm{C}_{2} \mathrm{O}_{4}\right)_{3}\right]$, существенно различается. В последнем случае АОА отличается существенным количеством сорбированной и химически связанной влаги и присутствием фаз гидраргиллита и бёмита на фоне практически полного отсутствия негидратированного оксида алюминия.

На рис. 7 показан рентгенодифракционный спектр $\mathrm{AOA}$, изображенного на рис. $6, c, d$. На дифрактограммах обеих сторон образца присутствуют пять пиков с максимумами, соответствующими значениям $2 \theta 38.47$, $44.72,65.10,78.20$ и $82.31^{\circ}$. Эти результаты хорошо согласуются с данными базы International Centre for Diffraction Data (ICDD) [58], файлы 85-1327, 89-2769 и результатами данной работы [59]. Интенсивности указанных пиков существенно различаются для обеих сто- 
рон. Интенсивности рентгенодифракционных максимумов, соответствующих фазе металлического алюминия, велики для стороны, обращенной во время анодирования от катода (изображена на рис. 6, d), хорошо видны все четыре указанных пика. В то же время рентгенодифракционная картина стороны, ориентированной во время анодирования к катоду (рис. 6,c), существенно отличается. Во-первых, интенсивность рентгенодифракционных откликов, соответствующих металлическому алюминию, заметно уменьшилась. Во-вторых, наблюдаются 2 широких пика с максимумами, соответствующими примерно значениям $2 \theta 29$ и $68^{\circ}$. Эти пики обусловлены наличием слоя АОА. Его же присутствие за счет поглощения рентгеновского излучения в значительной степени препятствует и появлению максимумов, характерных для фазы металлического алюминия, который находится под достаточно толстым оксидным слоем. В то же время дифракция рентгеновского луча на слое АОА практически отсутствует на кривой, полученной для стороны, обращенной от катода. Это свидетельствует о существенном различии толщин пленок AOA, сформированных на разных сторонах анода, что хорошо согласуется как с оптическими изображениями (рис. $6, c, d$ ), так и с результатами изучения ИК спектроскопических (рис. $4, f$ ) и ФЛ (рис. 5, $b-f$ ) свойств. Предположение о том, что широкие пики в областях $2 \theta 20-40^{\circ}$ и 55-80 ется анализом соответствующих данных базы ICDD. На рентгенодифракционных спектрах практически любой модификации оксида алюминия присутствуют интенсивные пики в указанных областях (например, файлы базы данных PDF2 31-0026, 46-1215, 04-0876, 08-0013, 09-0440, 52-0803, 71-1125, 79-1559 и др.), которые в материале со значительным разупорядочением структуры неизбежно подвергнутся значительному „размытию“. С другой стороны, известны работы, рассматривающие структуру пористого АОА, сформированного как в растворах щавелевой кислоты (наиболее близкие условия) [60-65], так и в других электролитах [20,63,64], в которых AOA присуща аналогичная рентгенодифракционная картина, характерная для рентгеноаморфного материала.

Рассмотрение рентгенодифракционных спектров, представленных на рис. 7, не выявило существенных отличий от ранее опубликованных результатов, но еще раз подтвердило вывод о том, что исследованный электролит анодирования обладает малой рассеивающей способностью, и образование АОА зависит от ориентации поверхности анода относительно катода на стороне, обращенной к катоду, а толщина формирующегося АОА больше, чем на стороне, обращенной от катода.

\section{Заключение}

Алюминий высокой чистоты был подготовлен путем термической и механической обработки и гальваностатически проанодирован с различными плотностями тока
$1.5-1.10 \cdot 10^{2} \mathrm{~mA} \cdot \mathrm{cm}^{-2}$ и $11.5-30 \mathrm{~mA} \cdot \mathrm{cm}^{-2}$ в водных растворах комплексных соединений $\mathrm{K}_{2}[\mathrm{Co}(e d t a)]$ и $\mathrm{K}_{2}[\mathrm{Zn}(e d t a)]$ различной концентрации соответственно. В результате исследования процессов анодирования, морфологии, состава и фотолюминесценции было установлено:

1. Процесс анодирования в $\mathrm{K}_{2}[\mathrm{Co}(e d t a)]$, несмотря на интенсивное перемешивание и невысокие значения плотностей анодного тока, сопровождается ярко выраженным явлением „подгорания“, что характеризуется хаотичными осцилляциями анодного напряжения на кинетике.

2. Кинетика анодирования в $\mathrm{K}_{2}[\mathrm{Zn}($ edta $)]$ имеет характерные осцилляции, носящие периодический характер и отличающиеся значительной амплитудой и регулярностью, указывающие на протекание колебательной электрохимической реакции.

3. Кинетика анодирования в $\mathrm{K}_{3}\left[\mathrm{Co}\left(\mathrm{C}_{2} \mathrm{O}_{4}\right)_{3}\right]$ имеет периодические осцилляции, характеризующиеся большей частотой и меньшей амплитудой, чем в случае анодирования в $\mathrm{K}_{2}[\mathrm{Zn}(e d t a)]$.

4. На поверхности анодного оксида, сформированного в $\mathrm{K}_{2}[\mathrm{Zn}(e d t a)]$ при невысокой плотности тока $\left(1.5 \mathrm{~mA} \cdot \mathrm{cm}^{-2}\right)$, образуются выступы, которые при повышении плотности тока $\left(4.0 \mathrm{~mA} \cdot \mathrm{cm}^{-2}\right)$ сливаются в сплошные растрескивающиеся поля. При дальнейшем повышениија $\left(10.0 \mathrm{~mA} \cdot \mathrm{cm}^{-2}\right)$ происходит образование „чешуйчатых“ (или „рыхлых“) выступов, размеры и поверхностная плотность которых растут с дальнейшим повышением плотности тока и продолжительности анодирования.

5. На поверхности оксида, сформированного в $\mathrm{K}_{3}\left[\mathrm{Co}\left(\mathrm{C}_{2} \mathrm{O}_{4}\right)_{3}\right]$, также образуются выступы, имеющие коническую форму и форму четырехугольной пирамиды. При повышении плотности тока данные выступы сливаются в сплошные поля. Поверхностная плотность таких выступов зависит от ориентации поверхности анода и всегда выше на стороне, ориентированной к катоду. Выступы, образующиеся при анодировании алюминия в $\mathrm{K}_{3}\left[\mathrm{Co}\left(\mathrm{C}_{2} \mathrm{O}_{4}\right)_{3}\right]$, не растрескиваются и не „шелушатся“.

6. Оже-электронные, электронно-зондовые и РФС анализы $\mathrm{AOA}$, сформированного в $\mathrm{K}_{2}[\mathrm{Zn}(e d t a)]$, показали наличие в его составе примеси углерода, азота и серы, причем последняя находилась в электролите в следовых количествах.

7. В результате анализа валентного состояния элементов оказалось, что оксид алюминия находится в виде $\alpha$ - или $\gamma$-модификации; углерод связан неполярной или слабополярной связью, типа $\mathrm{C}-\mathrm{C}, \mathrm{C}-\mathrm{H}$ или $\mathrm{C}-\mathrm{S}$; а сера присутствует в окисленном состоянии (т.е. действительно находится в виде сульфат-аниона).

8. Анализ спектров фотолюминесценции АОА, полученного в растворе $\mathrm{K}_{2}[\mathrm{Zn}(e d t a)]$, показал, что при значениях длин волн возбуждения 260 и $340 \mathrm{~nm}$ спектры практически не отличаются от спектров образцов, полученных в „традиционных“ кислотных электролитах. 
9. Установлено, что спектры фотолюминесценции AOA, сформированного в растворах $\mathrm{K}_{3}\left[\mathrm{Co}\left(\mathrm{C}_{2} \mathrm{O}_{4}\right)_{3}\right]$, характеризуются более сложной формой колокола и наличием второго максимума, который быстро убывает с увеличением длины волны возбуждения. Оказалось, что такие особенности характерны для АОА, сформированного только на стороне, ориентированной к катоду и отличающейся большим количеством выступов.

10. Установлено, что оксиды, сформированные в растворе $\mathrm{K}_{2}[\mathrm{Zn}(e d t a)]$, имеют высокое поглощение не только в видимой области, но и в исследованном ИК диапазоне. В наиболее длинноволновой области $\left(800-400 \mathrm{~cm}^{-1}\right)-$ области наибольшей прозрачности данного образца, относительное пропускание едва достигает $20 \%$.

11. Рентгенодифракционные исследования показали, что сформированный в растворе $\mathrm{K}_{3}\left[\mathrm{Co}\left(\mathrm{C}_{2} \mathrm{O}_{4}\right)_{3}\right]$ образец анодного оксида алюминия является рентгеноаморфным материалом, а толщина оксида, образовавшегося на стороне анода, обращенной к катоду выше, чем на стороне, обращенной в противоположную сторону.

Выполненное исследование освещает некоторые особенности процесса анодирования алюминия в растворах хелатных комплексных соединений, строения, структуры, состава, ИК спектроскопических и фотолюминесцентных свойств, сформированных в указанных электролитах анодных оксидных пленок на алюминии, и является важным этапом при разработке подходов к формированию анодного оксида алюминия с заданным составом, электрическими и оптическими характеристиками.

\section{Благодарности}

Авторы выражают благодарность Оргкомитету XXV Международного симпозиума „Нанофизика и наноэлектроника“ за возможность представить результаты исследований. Авторы благодарят также У. Туровец из Белорусского государственного университета информатики и радиоэлектроники за помощь в подготовке иллюстративного материала, Х. Хильдебранд из Фридрих-Александер университета Эрланген-Нюрнберг (Германия) за помощь в проведении электронномикроскопических исследований, С. Лазарука из Белорусского государственного университета информатики и радиоэлектроники за результативные дискуссии и Ю. Радюша из Научно-практического центра Национальной академии наук Беларуси по материаловедению за помощь в проведении рентгенодифракционных исследований.

\section{Финансирование работы}

Работа выполнена при поддержке государственных программ научных исследований Республики Беларусь „Конвергенция-2025“ (задания 3.03.3, 2.2.6), „Материаловедение, новые материалы и технологии“ (зада- ние 2.02) и „Цифровые и космические технологии, безопасность общества и государства“ (задание 1.10.7), Белорусский республиканский фонд фундаментальных исследований (БРФФИ), БРФФИ-ПТИ, грант Т20РТЁ-006 Часть исследований осуществлена благодаря поддержке Немецкой службы академических обменов (Deutscher Akademischer Austauschdienst, DAAD).

\section{Конфликт интересов}

Авторы заявляют, что у них нет конфликта интересов.

\section{Список литературы}

[1] Y. Lin, G.S. Wu, X.Y. Yuan, T. Xie, L.D. Zhang. J. Phys. Condens. Matter. IOP Publishing, 15 (17). 2917 (2003).

[2] G. Gorokh, A. Mozalev, D. Solovei, V. Khatko, E. Llobet, X. Correig. Electrochim. Acta. 52 (4), 1771 (2006).

[3] G. Gorokh, I. Obukhov, A. Poznyak, A. Lozovenko, A. Zakhlebaeva, E. Sochneva. 22nd International Crimean Conf. „Microwave \& Telecommunication Technol" (IEEE, Sevastopol, 2012), p. 655.

[4] A.N. Pligovka, A.N. Luferov, R.F. Nosik, A.M. Mozalev. 20th Intern. Crimean Conf. „Microwave \& Telecommunication Technol.“(IEEE, Sevastopol, 2010), p. 880. DOI: 10.1109/CRMICO.2010.5632734

[5] W. Lee, S.J. Park. Chem. Rev., $114(15), 7487$ (2014). DOI: $10.1021 / \mathrm{cr} 500002 \mathrm{z}$

[6] A. Brzózka, A. Brudzisz, K. Hnida, G.D. Sulka. Springer Series in Materials Science (Springer Verlag, 2015), v. 220. p. 219. DOI: 10.1007/978-3-319-20346-1_8

[7] A. Santos. J. Mater. Chem. C. Royal Society Chem., 5 (23), 5581 (2017).

[8] N. Bogomazova, G. Gorokh, A. Zakhlebayeva, A. Pligovka, A. Murashkevich, T. Galkovsky. J. Phys. Conf. Ser., 1124 (8), 081032 (2018).

[9] G.G. Gorokh, I.A. Taratyn, A.N. Pligovka, A.A. Lazavenka, A.I. Zakhlebayeva. Dokl. BGUIR., 7 (125), 51 (2019).

[10] J.T. Domagalski, E. Xifre-Perez, L.F. Marsal. Nanomaterials. MDPI AG, 11 (2), 430 (2021).

[11] H. Tsuchiya, P. Schmuki. Electrochem. Commun., 7 (1), 49 (2005).

[12] N. Verma, J. Jindal, K.C. Singh, A. Mittal. Advanced Coating Materials (John Wiley \& Sons, Inc., Hoboken, NJ, USA, 2018), December, p. 235.

[13] G.A. Ermolaev, S.E. Kushnir, N.A. Sapoletova, K.S. Napolskii. Nanomaterials. MDPI AG, 9 (4), 651 (2019).

[14] A.I. Sadykov, S.E. Kushnir, N.A. Sapoletova, V.K. Ivanov, K.S. Napolskii. Scr. Mater. Elsevier Ltd, 178, 13 (2020).

[15] Ю.Ю. Лурье. Справочник по аналитической химии 6-е изд. (АльянС, М., 2017), 448 с.

[16] S. Tajima, N. Baba, M. Shimura. Electrochim. Acta. Pergamon, 12 (8), 955 (1967).

[17] G.C. Wood et al. J. Electrochem. Soc. 143 (1), 74 (1996).

[18] A. Mozalev, A. Poznyak, I. Mozaleva, A.W. Hassel. Electrochem. Commun. 3 (6), 299 (2001). DOI: $10.1016 / \mathrm{S} 1388-2481(01) 00157-6$

[19] S.K. Lazarouk, D.A. Sasinovich, V.E. Borisenko, A. Muravski, V. Chigrinov, H.S. Kwok. J. Appl. Phys. 107 (3), 033527 (2010).

[20] A. Poznyak, A. Pligovka, T. Laryn, M. Salerno. Materials (Basel). Multidisciplinary Digital Publishing Institute, 14 (4), 767 (2021). 
[21] J.W. Diggle, T.C. Downie, C.W. Goulding. Chem. Rev. American. Chem. Society, 69 (3), 365 (1969).

[22] Н.Б. Березин, Н.В. Гудин, А.Г. Филлипова, В.В. Чевела, Ж.В. Межевич, Э.Д. Яхьев, К.А. Сагдеев. Электроосажсдение металлов и сплавов из водных растворов комплексных соединений (Изд-во Казанского гос. техн. ун-та, Казань, 2006), 276 с.

[23] В.В. Зенин, А.А. Стоянов, С.В. Петров, Б.А. Спиридонов. Микроэлектроника, 42 (5), 361 (2013).

[24] L. de Riese-Meyer, V. Sander. Aluminium, 2, 155 (1992).

[25] В.Ф. Сурганов, А.А. Позняк. ЖПХ 71 (2), 253 (1998) [D.F. Surganov, A.A. Poznyak. Russ. J. Appl. Chem., 71 (2), 253 (1998)]

[26] A. Mozalev, I. Mozaleva, M. Sakairi, H. Takahashi. Electrochim. Acta., 50 (25-26), 5065 (2005).

[27] I. Kleschenko, M. Rezvanova, A. Poznyak. 2006 16th International Crimean Microwave and Telecommunication Technology. IEEE, 2006. P. 675.

[28] T. Lednický, A. Mozalev. NANOCON 2015 - 7th Int. Conf. Nanomater. - Res. Appl. Conf. Proc. 265 (2015).

[29] А.А. Позняк. Электрохимические и электролитноплазменные методы модификации металлических поверхностей: Тезисы докладов Междунар. научно- технической конб. (КГУ, Кострома, 2003), с. 38.

[30] С.В. Головатая, О.И. Зубаревич, Г. Кнёрншильд, Е.В. Муравицкая, А.А. Позняк. Современные средства связи: материалы ХI Межсдунар. научно-технической конф. (Бестпринт, Минск, 2006), с. 72.

[31] С.В. Головатая, О.И. Зубаревич, Г. Кнёрншильд, А.А. Позняк. Современные средства связи: Материаль ХІІ Междунар. научно-технической конф. (ВГКС, Минск, 2007), с. 68.

[32] S.V. Golovataya, O.I. Zybarevich, G. Knörnschild, E.V. Muravitskay, A.A.Poznyak. 18th International Crimean Conference „Microwave \& Telecommunication Technol" (IEEE, Sevastopol, 2008), p. 581. DOI: $10.1109 / C R M I C O .2008 .4676512$

[33] С.В. Головатая, Н.В. Ковальчук, А.А. Позняк. Современные средства связи: материалы ХIV Международной научно-технической конференции (ВГКС, Минск, 2009), c. 102.

[34] С.В. Головатая, А.Г. Кароза, Н.В. Ковальчук, А.А. Позняк. Современные средства связи: материалы XIV Междунар. научно-технической конф. (ВГКС, Минск, 2009), c. 104.

[35] A.A. Poznyak, G. Knoernshild, A.G. Karoza. 21st International Crimean Conference „Microwave \& Telecommunication Technol." (IEEE, Sevastopol, 2011), p. 723.

[36] S.V. Golovataya, A.M. Mozalev, A.A. Poznyak. 16th International Conference ,Microwave \& Telecommunication Technol.“ (IEEE, Sevastopol, 2006), p. 606. DOI: $10.1109 /$ CRMICO.2006.256125

[37] А.М. Мозалев, И.И. Мозалева, А.А. Позняк. Докл. БГУИР, 2 (14), 127 (2006).

[38] G. Knörnschild, A.A. Poznyak, A.G. Karoza, A. Mozalev. Surf. Coatings Technol. Elsevier, 275, 17 (2015).

[39] А.А. Позняк. Анодный оксид алюминия и композитные материалы на его основе. Монография (Издат. центр БГУ, Минск, 2007), 252 p.

[40] Г.Г. Горох, А.М. Мозалев, А.А. Позняк. IX конференция молодых ученых и специалистов. Новосибирск, 1 (2), 9 (1988).
[41] А.А. Позняк, Г. Кнёрншильд, М. Штратманн. Актуальные проблемы твердотельной электроники и микроэлектроники: Tp. V Всерос. научно-технической конф. с международным участием (ТРТУ, Таганрог, 1998), с. 38.

[42] W.J. Stępniowski, M. Norek, M. Michalska-Domańska, A. Nowak-Stępniowska, A. Bombalska, M. Włodarski, Z. Bojar. Mater. Lett., 106, 242 (2013).

[43] А.И. Косевич. Дислокация. Физическая энциклопедия. Советская энциклопедия, 1, 636 (1988).

[44] В.В. Болдырев. Дефекты. Химическая энциклопедия. Советская энциклопедия, 2, 29 (1990).

[45] T.H. Nguyen, R.T. Foley. J. Electrochem. Soc. The Electrochem. Society, 126 (11), 1855 (1979).

[46] C.B. Bargeron, R.B. Givens. J. Electrochem. Soc. The Electrochem. Society, 124 (8), 1230 (1977).

[47] А.М. Жаботинский. Колебательные реакции. Химическая энциклопедия. Советская энциклопедия, 1990. С. 428-430.

[48] В.В. Нечипорук, И.Л. Эльгурт. Самоорганизация в электрохимических системах (Наука, М., 1992), 168 с.

[49] S. Ono, M. Saito, M. Ishiguro, H.J. Asoh. J. Electrochem. Soc., $151(8)$, B473 (2004).

[50] T. Aerts, I. De Graeve, H. Terryn. Electrochim. Acta., 54 (2), 270 (2008)

[51] F. Zhou, A.K. Mohamed Al-Zenati, A. Baron-Wiecheć, M. Curioni, S.J. Garcia-Vergara, H. Habazaki, P. Skeldon, G.E. Thompson. J. Electrochem. Soc. The Electrochem. Society, 158 (6), 202 (2011).

[52] N.M. Yakovleva, A.M. Shul'ga, K.V. Stepanova, A.N. Kokatev, V. Rudnev, I.V. Lukiynchuk, V.G. Kuryavyi. Kondensirovannye Sredy I Mezhfaznye Granitsy Condensed. Matter and Interphases, 22 (1), 124 (2020). DOI: $10.17308 / \mathrm{kcmf} .2020 .22 / 2536$

[53] K.V. Stepanova, A. Shul'ga, N. Yakovleva, A.N. Kokatev. Trans. Kola Sci. Cent. Kola Science Centre, 11 (3), 185 (2020).

[54] T.A. Carlson. Photoelectron and Auger Spectroscopy (MA: Springer US Boston, 1975), 1-417 p.

[55] E. Hornbogen, B. Skrotzki. Werkstoff-Mikroskopie (Springer, Berlin Heidelberg, 1993), v. 11, 232 p.

[56] Р.И. Агладзе и др. Прикладная электрохимия (учебник), под ред. Кудрявцева Н.Т. (Химия, М., 1975), 551 с.

[57] Г.Г. Горох. Высокочастотные планарные индуктивноемкостные элементы интегральных микросхем на основе слоев алюминия и его анодного оксида. Диссертация 05.27.01. Минский радиотехнический институт, 1989. $202 \mathrm{c}$.

[58] ICDD - International Centre for Diffraction Data [Electronic resource]. URL: https://www.icdd.com/ (accessed: 04.04.2021).

[59] T. Lebyedyeva, S. Kryvyi, P. Lytvyn, M. Skoryk, P. Shpylovyy. Nanoscale Res. Lett., 11 (1), 203 (2016).

[60] L. Zhou, Y. Guo, M. Yagi, M. Sakurai, H. Kameyama. Int. J. Hydrogen Energy, 34 (2), 844 (2009).

[61] T. Masuda, H. Asoh, S. Haraguchi, S. Ono. Electrochemisty, 82 (6), 448 (2014). DOI: 10.5796/electrochemisty. 82.448

[62] T. Masuda, H. Asoh, S. Haraguchi, S. Ono. Materials (Basel). MDPI AG, 8 (3), 1350 (2015).

[63] S.S. M, P.R. Reddy, N.K. Udayashankar. AIP Conf. Proceed. American Institute of Phys. Inc., 1728 (2), 020407 (2016). DOI: $10.1063 / 1.4946458$

[64] P.R. Reddy, K.M. Ajith, N.K. Udayashankar. Appl. Phys. A, 124 (11), 765 (2018).

[65] P. Ramana Reddy, K.M. Ajith, N.K. Udayashankar. Mater. Sci. in Semicond. Process., 106, 104755 (2020). DOI: $10.1016 /$ j.mssp.2019.104755 